Van Yüzüncü Yil Üniversitesi
Tarim Bilimleri Dergisi

Araştırma Makalesi (Research Article)

An Alternative Live Food for Fish Larvae;

Vinegar Eels (Turbatrix aceti) Enriched with Bacterial Protein

\author{
Şükrü ÖNALAN ${ }^{* 1}$, Ahmet SEPIL ${ }^{1}$ \\ ${ }^{1}$ Van Yuzuncu Yil University, Fisheries Faculty, 65080, Van, Turkey \\ *Corresponding Author e-mail: sukruonalan@yyu.edu.tr
}

\section{Article Info}

Received: 10.11.2019

Accepted: 05.12.2019

Online Published 31.12.2019

DOI: $10.29133 /$ yyutbd.644877

\section{Keywords}

Bacterial protein,

Fish larvae,

L. garvieae,

Real-Time PCR,

Vinegar eels,

Zebra fish.

\begin{abstract}
Especially at commercial rearing of marine and ornamental fish species, the achievement of early stage feeding operations is very significant for reducing larval loses. For this reason, it is necessary to produce and use of live food organisms that appropriate for first mouth gap sizes of fish larvae. Widely used in this regard rotifer (Brachionus plicatilis) has got uneasy culture procedures, so evaluating alternative live food organisms is very important. In this study, we have assessed the feasibility of vinegar eels in early stage feeding of altricial fish larvae. Zebra fish (Danio rerio) have got smaller mouth gap size than other fish species have been used in feeding trials and acceptabilities of vinegar eels by larvae was evaluated. And also, an increase in protein contents of vinegar eel evaluated using bacterial proteins (Lactococcus garvieae).
\end{abstract}

\title{
Balık Larvaları için Alternatif bir Canlı Yem; Bakteriyel Protein ile Zenginleştirilmiş Sirke Kurtları (Turbatrix aceti)
}

\section{Makale Bilgileri}

Geliş: 10.11 .2019

Kabul: 05.12.2019

Online Yayınlanma 31.12.2019

DOI: $10.29133 /$ yyutbd.644877

\section{Anahtar kelimeler}

Bakteriyel protein,

Balık larvası,

L. garvieae,

Real-Time PCR,

Sirke kurdu,

Zebra balığı.
Öz: Özellikle deniz ve süs balıkları türlerinin ticari olarak yetiştirilmesinde erken evre besleme işlemlerinin başarılması larva kayıplarını azaltmak için çok önemlidir. Bu nedenle, ilk ağız boşluğu büyüklüğünde balık larvaları için uygun canlı gıda organizmalarının üretilmesi ve kullanılması gerekmektedir. $\mathrm{Bu}$ konuda yaygın olarak kullanılan rotifer (Brachionus plicatilis), kolay olmayan kültür prosedürlerine sahiptir, bu nedenle alternatif canlı gıda organizmalarının değerlendirilmesi çok önemlidir. Bu çalışmada altrisayal balık larvalarının erken beslenme evresinde sirke kurdunun canlı yem olarak uygulanabilirliği denenmiştir. Diğer balık türlerinin beslenme denemelerinde kullanılandan daha küçük ağız boşluğu büyüklüğüne sahip olan Zebra balığı (Danio rerio)'nın sirke kurtlarını canlı yem olarak kabul edilebilirlikleri değerlendirilmiştir. Sirke kurtlarının beslenmesinde ise bakteriyel (Lactococcus garvieae) proteinlerin kullanımı değerlendirilmiştir.

\section{Introduction}

A major bottleneck in the production of altricial fish larvae is inadequate nutrition during the early stages. In spite of improvements in microparticulate diet technology, exclusive use of formulated diets is problematic and currently, feeding larval fish with live food organisms during early stages 
results in higher growth and survival rates (Önal et al., 2015). Especially at commercial rearing of ornamental fish larvae, early stage feeding is very significant to reduce larval loses. For this reason, it is necessary to produce and use live feeds suitable to the mouth gap of larvae.

The brackish water rotifer, Brachionus plicatilis, is one of the most important live food organisms that are extensively used for the fish culture of most altricial larvae all over the world (Önal et al., 2015). However various contamination problems faced while rearing rotifer and due to the difficulties of rearing procedures, it is a bottleneck at larval feeding especially commercial rearing of ornamental fish. The beginning time of exogenous feeding at altricial fish larvae differ according to species. Generally, the mouth apertures of larvae at this stage is quite big. Therefore, it is necessary to feed the larvae with suitable size live feeds. It is quite important that the live feed which will be used at larval feeding must be acceptable by the larvae besides the sizes of live feeds. It is necessary to use live feeds which are quite motile at the water column to interest larvae. Because of some difficulties at intensive rearing and stocking of live feeds generally popular food at early stage feeding is egg yolk at commercial rearing of ornamental fish larvae in our country. But, due to the immobility of egg yolk at water column and formation of the layer which will damage water quality at the aquarium floor increase larval mortality. However, at early stages due to immaturity of the digestive system of larvae and inadequate level enzyme activities it is necessary to use live feeds and because of this situation it is mandatory to use alternative live feeds. In this study the usability of a free living nematode species vinegar eel (Turbatrix aceti) at larval feeding and enrichment of composed culture with bacterial proteins is evaluated.

In aquaculture, Lactococcus garvieae is an important bacterium at the head of bacterial factors in our country (Çağırgan, 2004). Lactococcus garvieae causing Laktokokkozis is a septicemic disease that emergent depending upon temperature increase. And then it leads to economic casualties in fresh water and marine fishes (Ghittino and Prearo, 1992; Carson et al., 1993; Bark and McGregor, 2001; Diler et al., 2002; Eyngor et al., 2004; Vendrell et al., 2006; Savvidis et al., 2007; Evans et al., 2009). Species of belonging to genus Lactococcus take place within the family Streptococcaceae. Streptokokkozis disease in rainbow trout has reported in Japan in 1958 by Hoshina for the first time. In our country, Streptokokkozis has reported in Karacasu county of Aydin province in small family management in 1992 for the first time (Çağırgan, 2004). At the same year, 5 different epizooties have appeared in the same management. In 1993, while the water temperature at $12{ }^{\circ} \mathrm{C}$, plenty of Lactococcus isolated from the intestine system of fishes. When the water temperature has increased to $15{ }^{\circ} \mathrm{C}$ degrees, it caused 60 percent of mortality within 3 days. Laktokokkozis disease has also begun to be seen at other trout farms when the water temperature above $15^{\circ} \mathrm{C}$ in 2000 . Almost all of the trout farms to spread and has caused serious losses by the way of transferring pathogenic fishes.

\section{Materials and Methods}

First of all, we have aimed to breed vinegar eels in prepared culture media. For that purpose, culture media was composed as 1 liter glass jars including fifty percent of cider vinegar and fifty percent of apple juice. Vinegar ells were obtained from stock culture was inoculated into culture media for breeding. However, an altricial ornamental fish larvae have got suitable mouth gap is determined to using for vinegar eels as live food. So, Zebrafish (Danio rerio Hamilton, 1822) from the family Cyprinidae was chosen. These fishes have long been used in biomedical research and testing, in the last years has the zebrafish (Danio rerio) become an important research tool (Francis-West et al., 1995). Zebrafish is important for the aquarium sector as well as model fish species for biological science. Zebrafish have got transparent larvae in early life stages and reproduction capacities are higher than the other many ornamental fish species. And also these fishes have got easy culture and stocking procedures. Zebrafish is an important laboratory model for studies of genetics and disease due to have got fast growth performance and genotype specifics similar to human (Lamason et al., 2005). Aquariums and fed on kind of live foods (Blood worms and sludge worms) and commercial flake baits for during 2 weeks. After the adaptation period, suitable water quality parameters for this species were provided and eggs were taken from mature fishes. 


\subsection{Morphological measurements on larvae and vinegar eels}

First feeding of Zebra fish larvae on $3^{\text {rd }}$ day after yolk absorption (3 DAH-3 Day After Hatching) and also mouth gap is opened at $3 \mathrm{DAH}$. Vinegar eels were offered to larvae during the first day of exogenous feeding. Mouth gap sizes when it first opened of larvae and live bait sizes and shapes are essential for using live bait efficiently. So, we have performed some measurements on larvae and vinegar eels. 20 larvae were selected randomly in larvae tank at 3 DAH and mouth gap sizes were measured with the stereo microscope. In addition, 20 eels were taken randomly from culture media at the end of a 15-day culture period and eels were measured using binocular microscope.

\subsection{Acceptability experiments with fish larvae}

30 larvae were taken randomly from inside of larvae tank and transferred to $500 \mathrm{ml}$. beaker with the inclusion of $25{ }^{\circ} \mathrm{C}$ distilled water, in order to determine whether vinegar eels have been received by larvae. An aquarium heater $(25 \mathrm{~W})$ for maintaining at $25{ }^{\circ} \mathrm{C}$ and an air stone for water circulation were installed into the beaker. Since the opening of the mouth, not any baits were added into larvae tank. Just after larvae were taken into the beaker, not any baits were added to beaker for a period of 12 hours for the stomach and the digestive tract is completely empty. At the end of 12 hours, vinegar eels were added into beaker as 25 eels $/ 100 \mathrm{ml}$. Larvae were randomly taken from the beaker end of the 10. 30. and 60. minutes and larvae were investigated to evaluate the digestive tract and stomach fullness with eels. After the first feeding, this process was repeated at $5 \mathrm{DAH}$ and $7 \mathrm{DAH}$. By the time the end of the feeding trial, all of the larvae were fed with only vinegar eels 2 times a day (Robin and Vincent, 2003).

\subsection{Bacteria isolation}

Bacterial isolates used in the study, were isolated from rainbow trout and identification has not been performed. Bacteria isolations were repeated having been incubated for a period of 24 hours at 22 ${ }^{\circ} \mathrm{C}$ in Tryptic Soy Agar (TSA). After the incubation period, colonies of bacteria were analyzed in terms of morphological features such as color, shape and brightness (Austin and Austin, 1999).

\subsection{Bacterial identification}

\subsubsection{DNA isolation}

Total genomic DNA isolations were insulated using DNA Mini Plus Kit (Qiagen) in QIAcube. Real-Time PCR analysis were carried out with a volume of $25 \mu 1$ mixture of specific forward, reverse primers (27F-1492R), SYBRGreen qPCR Mastermix and DNase-RNase free water (Önalan and Yavuz, 2019).

\subsubsection{Real-Time PCR operation}

In Real-Time PCR process, pre-denaturation was carried out at $95^{\circ} \mathrm{C}$ for $10 \mathrm{~min}$, denaturation $94{ }^{\circ} \mathrm{C}$ for $45 \mathrm{sec}$, anneling at $55^{\circ} \mathrm{C}$ for $30 \mathrm{sec}$ and extantion at $72{ }^{\circ} \mathrm{C}$ for $45 \mathrm{sec}$. Cycle was completed as 45 cycle. Then as the last step, last-extantion process was carried out at $72{ }^{\circ} \mathrm{C}$ for 7 minutes. During the Real-Time PCR operation, non-template control tubes were used as a negative control. In RotorGene Q 9000 software, sigmoidal curves have been commented as positive (Livak and Schmittgen, 2001; Altinok et al., 2007). 


\subsubsection{Sequence Analysis}

After the Real-time PCR analysis, sequence analysis of the target region was performed with PCR amplicons and Primers. Real-Time PCR operation was repeated for the purpose of cleaning the PCR amplicons. After that PCR amplicons were sent for sequence analysis. Results in PDF and Word format blast in NCBI web sites (Duman et al., 2017).

\subsection{Obtaining of bacterial protein}

In this process, developing colonies were cultivated to TSB medium after development at 37 ${ }^{\circ} \mathrm{C}$ for 24 hours in TSA medium. And then bacterial development was repeated in TSB medium at 37 ${ }^{\circ} \mathrm{C}$ for 24 hours. Developing bacteria have centrifuged in $10400 \mathrm{rpm}$ and bacteria pellets have obtained. $100 \mu \mathrm{l}$ of ultra-pure water adding onto bacteria pellet was made a suspension by pipetting. In order to obtain bacterial protein, bacterial suspension have centrifuged in $10000 \mathrm{rpm}$ for 5 minutes and supernatant of suspension were moved away. Cell lysis buffer adding onto bacteria pellet, cells have lysed by use of sonication. Homogenate has centrifuged in $14000 \mathrm{rpm}$ for 10 minutes and protein extracts were obtained. After the centrifuge process, supernatant has taken to Eppendorf tubes and concentration of homogenate was calculated using Bradford solution (Gorgisen ve ark., 2013).

\subsection{Calculation of the spectrophotometric development}

In order to calculate increase of the optical density as spectrophotometric that formed as a result of feeding on bacterial proteins;

a) Distilled water and vinegar eels,

b) Distilled water and protein,

c) Distilled water, protein and vinegar eels,

d) Distilled water, vinegar and vinegar eels,

e) Control,

A trial was established that above mentioned contents of 5 groups. In the experiment, the optical density at $600 \mathrm{~nm}$ synchronized as amount of vinegar eels were prorated to the groups with the inclusion of vinegar eels. Due to development an increase in densities were spectrophotometrically measured and results has been made graphically using by Graphpad Prism software (Çevik and Önalan, 2019).

\section{Results}

\subsection{Morphological measurement results}

The time of mouth opening 3. day (after hatching 74-75. hours), larvae were taken randomly and mouth gap sizes were measured. Larvae were placed vertically into the glass capillary tubes and mouth gap sizes were measured using stereo microscope. Accordingly, average of measurements was performed on the 20 larvae was determined as $124 \mu \mathrm{m}$ (Fig 1).

At the end of a 15-day culture period, vinegar eels were randomly taken and eels were measured. The thickness of body region of 50 eels were measured and average was determined as 57 $\mu \mathrm{m}$ (Fig 1). 


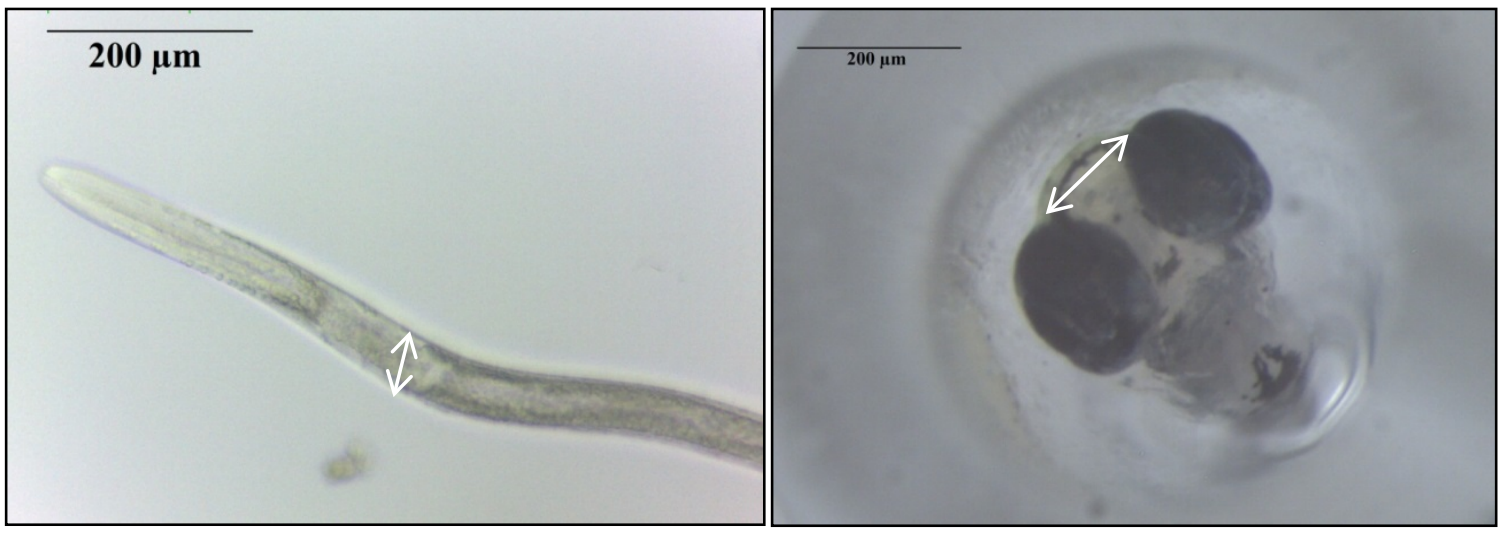

Figure 1. Vinegar eel diameter of body (widest part) and Larvae $(74 \mathrm{~h})$ mouth gap size.

\subsection{Feeding experiment results}

At the end of the feeding trials, vinegar eels were encountered throughout the digestive tract and stomach of larvae at 3 day after hatching (3 DAH) and the following days (Fig 2).

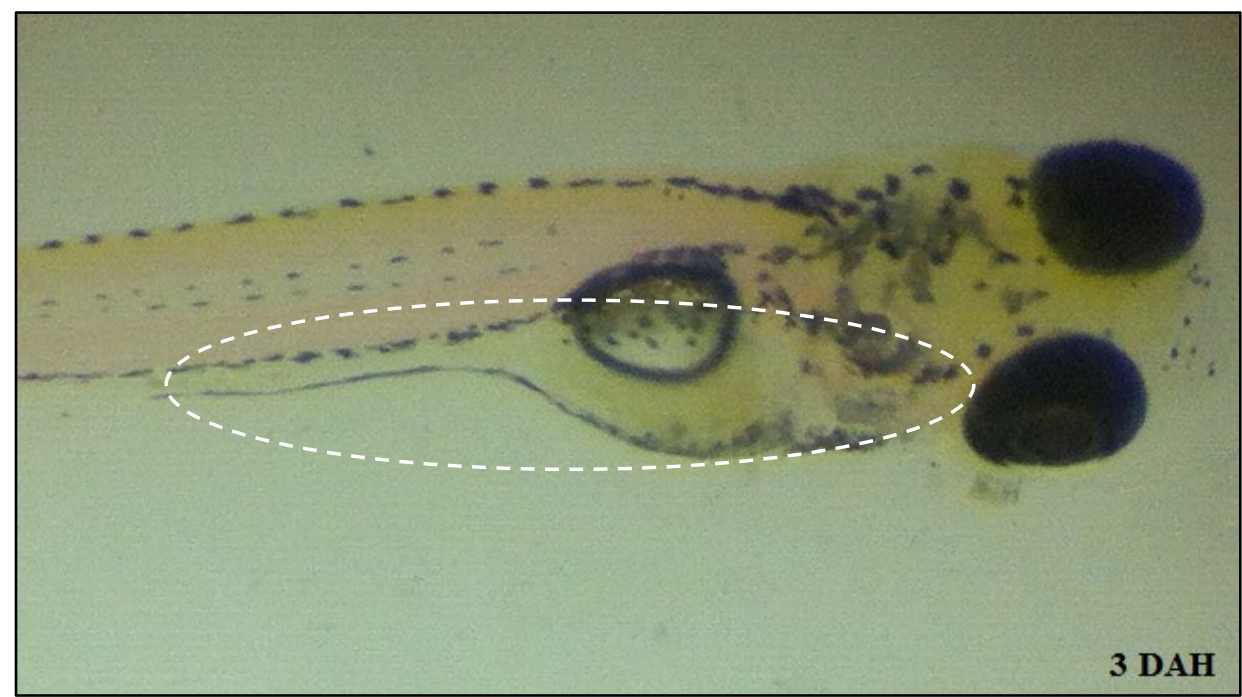

Figure 2. First feeding on vinegar eels.

Similarly, when feeding trial carried the following days, it has observed that use up vinegar eels and their stomach is full at 5 DAH and 7 DAH (Fig 3).

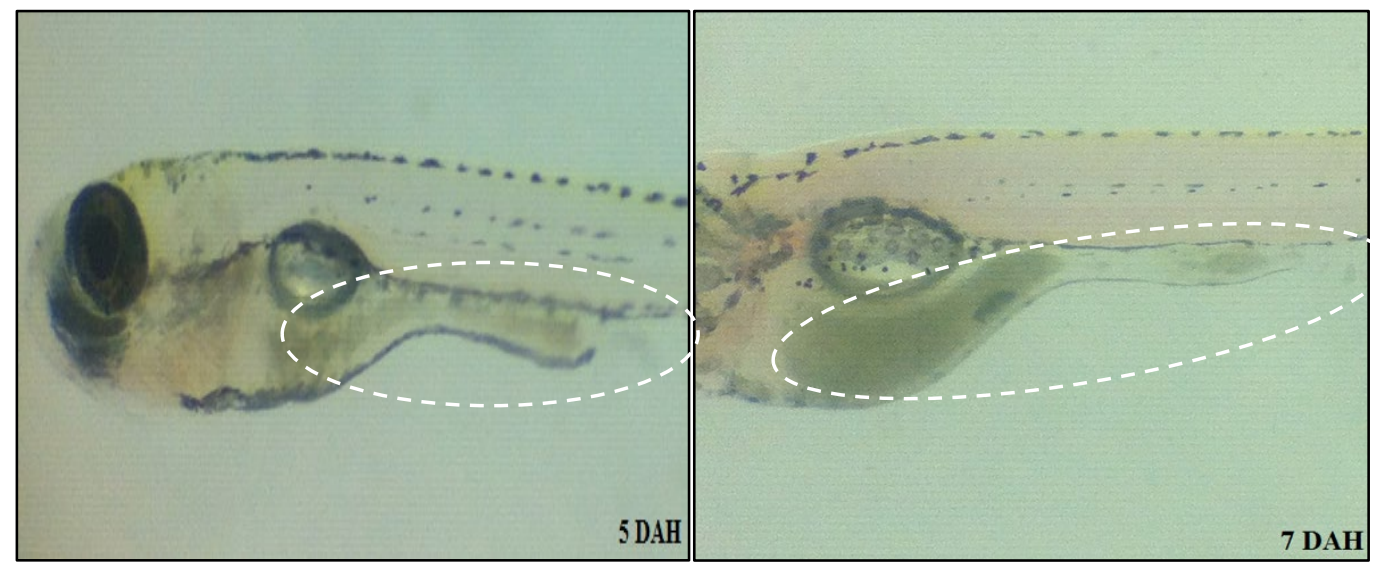

Figure 3.5 and 7. days after hatching digestive tract and stomach fullness with vinegar eels 


\subsection{Bacterial identification results}

In our study, with the aim of identification of L. garvieae using as source of protein in the diet of vinegar eels, as a result of sequence of amplicons were obtained from PCR (Fig 4), were confirmed as $L$. garvieae at the rate of \%96. Results of nucleic acid and amino acid sequence is given below (Fig $5,6)$.

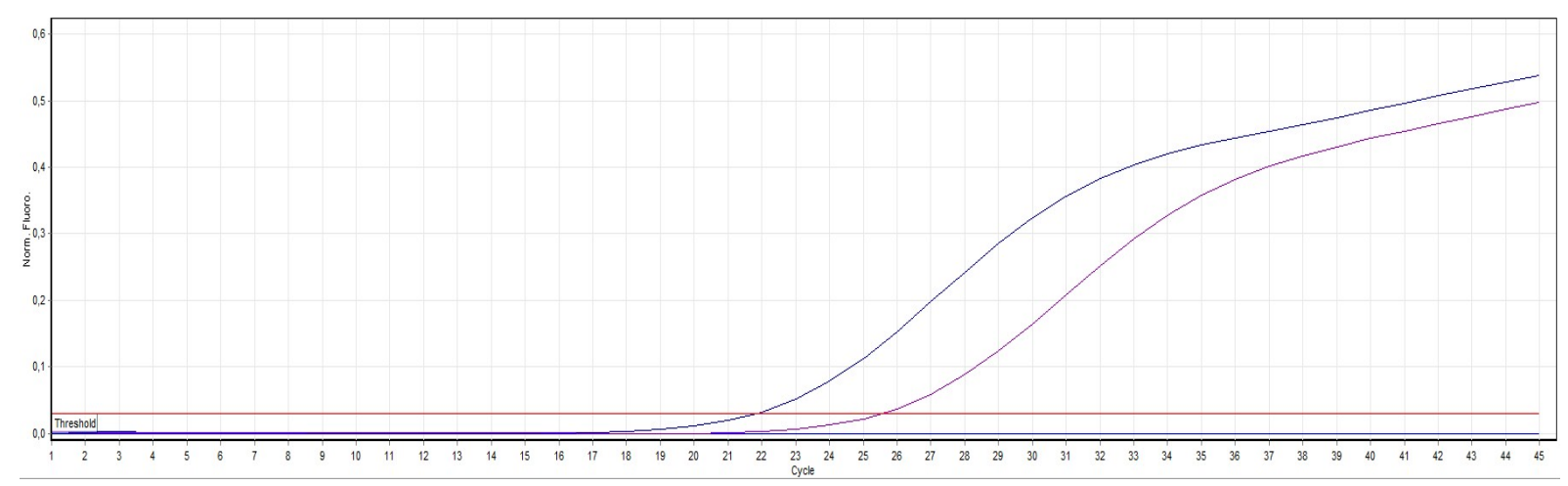

Sample-1 $\square$ Sample-2 $\square$ NC-1 $\square$ NC-2 $\square$ NTC

Figure 4. Real-Time PCR positive results of two same Lactococcus garvieae bacterial DNAs (*NC-1: Negative control (Master mix), NC-2: Negative control (Primer), NTC: Non-Template Control).

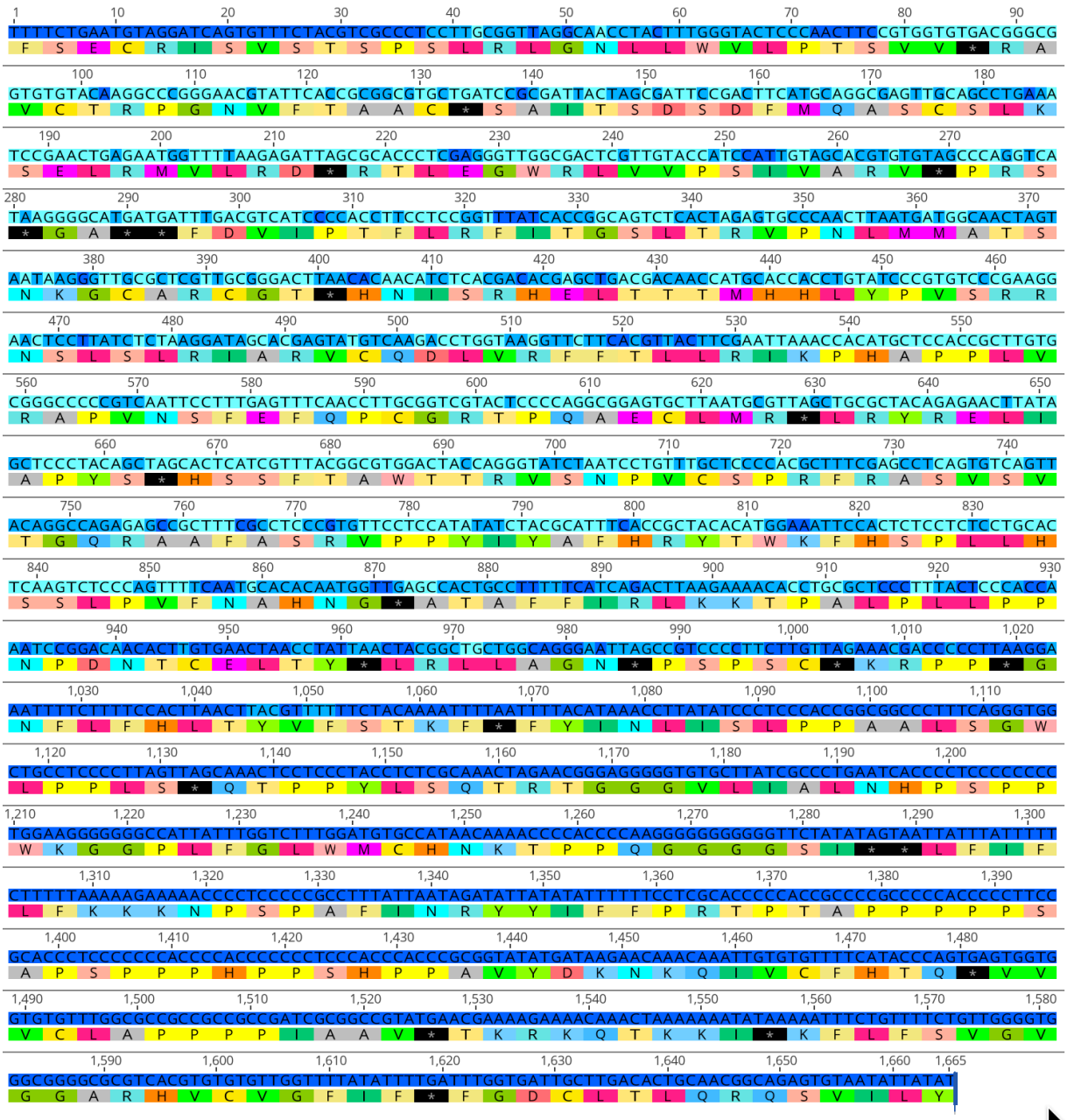

Figure 5. Amino acid and nucleic acid sequence of PCR amplicons. 


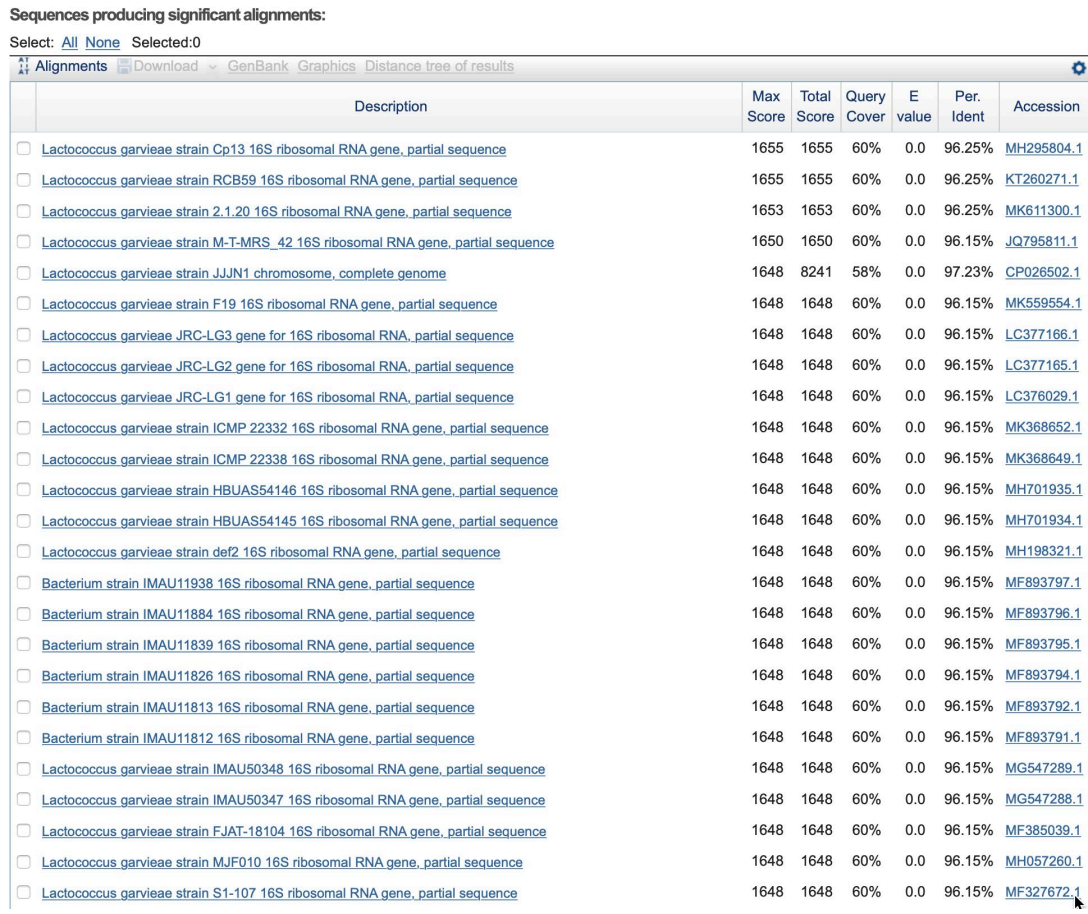

Figure 6. NCBI blast results of sequence results.

Obtained results of nucleic acid and amino acid sequences were blast by nblast method on the NCBI website. Obtained from results of the blast, according to above $\% 96$ similarity ratio identificate that L. garvieae.

\subsection{The results of using bacterial protein on feeding trial}

Proteins that obtained from L. garvieae isolates using Bradford method were used for feeding vinegar eels. Vinegar eels were used bacterial proteins contained within distilled water. Eels had stayed alive during the study period and also the presence of protein was monitored in digestive tract (Fig. 7).
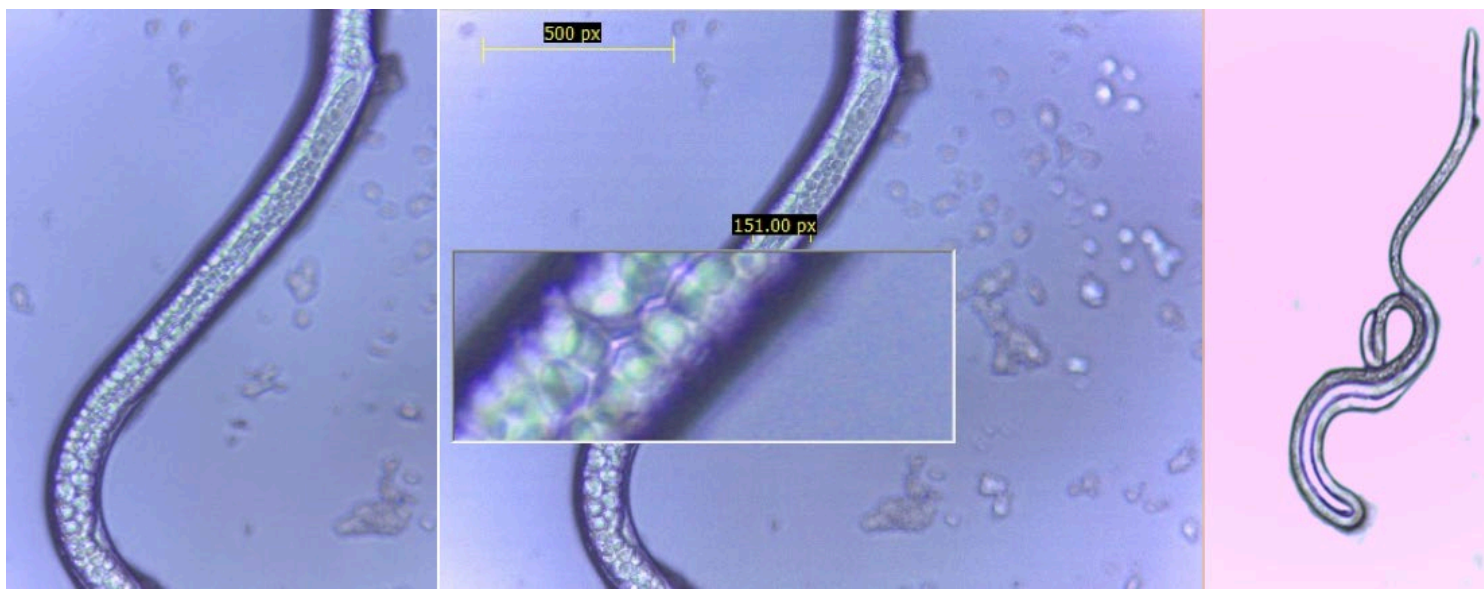

Figure 7. Bacterial proteins intake by vinegar eels.

Performed with Bradford method that in order to determine the increase in total protein amount depending upon vinegar eels feeding on protein. These total protein values are given below. 


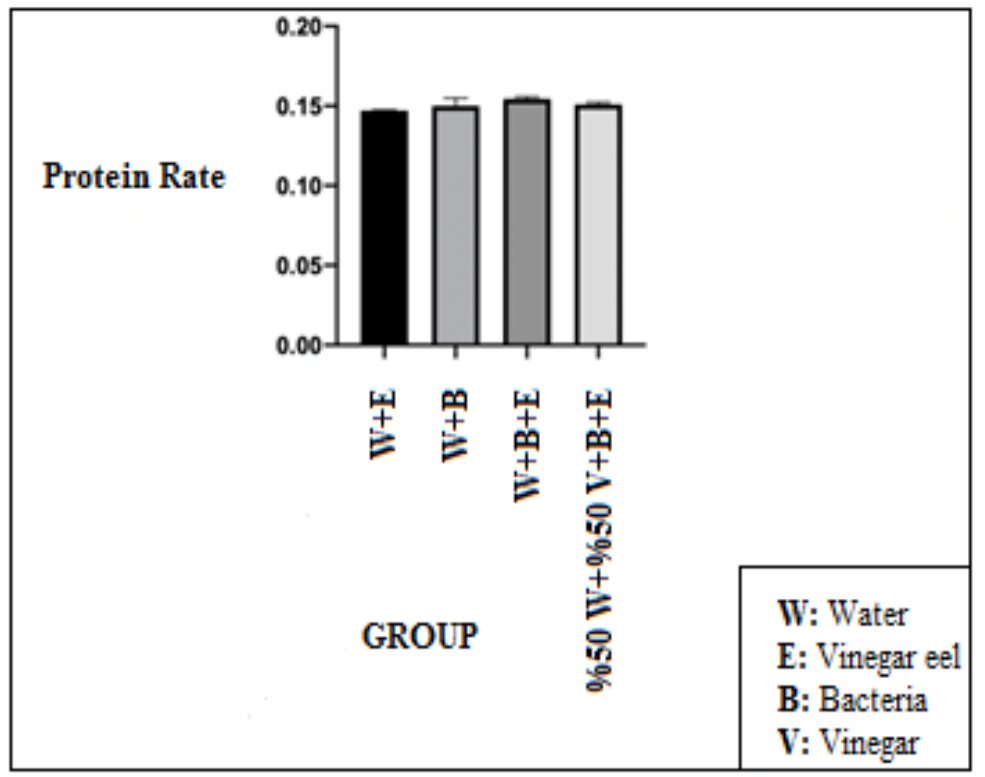

Figure 8. Total protein values of different groups.

\subsection{Spectrophotometric development results}

In different groups, depending on development of the vinegar eels, increase the density of the results are given below.

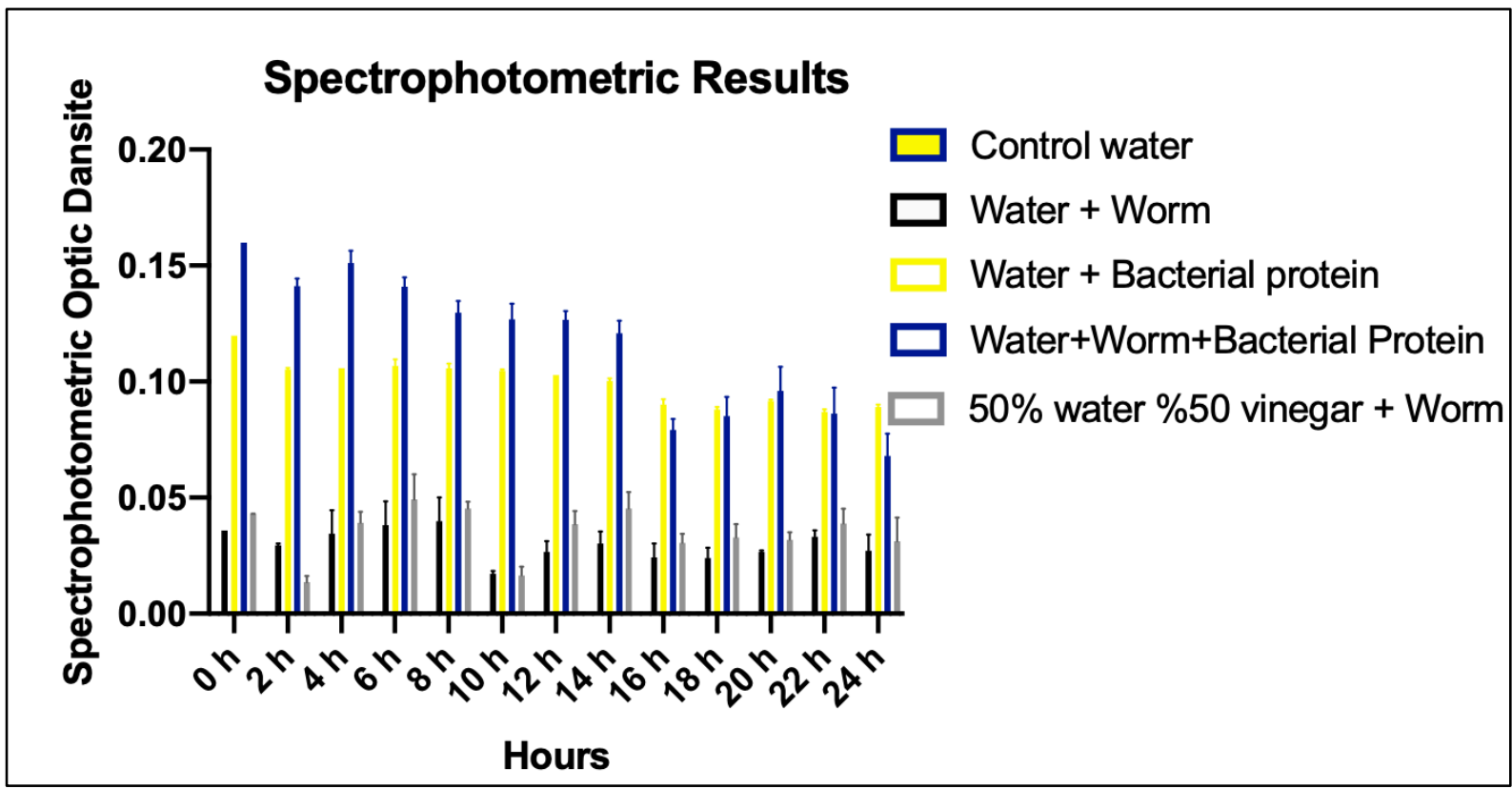

Figure 9. Density change depending upon development of eels.

In line with the results from the chart, development of optical density of eels feed on bacterial protein 3 fold more than vinegar eels in water. Similarly, development of optical density of eels feed on bacterial protein 2 fold more than development of eels in white vinegar.

\section{Discussion and Conclusion}

Morphological measurements on larvae and vinegar eels show that vinegar eels are a live feed that can be used in early stage larval feeding procedures. In addition, the detection of vinegar eels in the digestive tract of the larvae from the moment of exogenous feeding in the experiments reveals the 
acceptability of the larvae. The zebra larvae used in the study are altricial larvae with very small first mouth opening ( $3 \mathrm{DAH})$ and are generally used as a model for the first feeding species with rotifers. Therefore, it is thought that vinegar eels can be used for feeding species that are commercially grown and need rotifers similarly. In commercially dense bream (S. aurata) larvae, the first mouth opening is quite small as in zebra larvae. Therefore, the use of rotifers in larval breeding is essential. However, contamination problems encountered in rotifer cultures and sudden collapses in the population reveal the need for the alternative live feed. However, the acceptability of the feed by the larvae is largely related to the fact that the live feed is movable within the water column.

In the first steps of the study, vinegar eels were observed to survive at $-40{ }^{\circ} \mathrm{C}$ and $-80{ }^{\circ} \mathrm{C}$ after 1,5 and $10 \mathrm{~min}$. In a study conducted with vinegar eels, it was reported that they could survive at -77 ${ }^{\circ} \mathrm{C}$ (Gehenio and Luyet, 1951).

There are many studies conducted with bacterial proteins for different purposes (Williams et al., 1991; Øverland et al., 2001; Aas et al., 2006). However, no study has been found to feed vinegar eels which are used as live feeds for larval feeding of bacterial proteins. Although bacterial diseases have a very important place in the field of aquaculture, bacteria have been evaluated to benefit in many areas. Biodiesel production (Olguín, 2012), the production of yogurt (Lee et al., 1974), treatment with different bacteria against different bacterial diseases and biofilm (Høiby et al., 2010) in many areas such as bacteria-oriented solutions are used in different areas of life. The nutritional needs in the fisheries field is an important expense. Vinegar eels are highly mobile and have high tolerance to unfavorable environmental conditions, increasing the potential of being an alternative live feed in larval breeding. It is thought that the use of bacterial protein for feeding vinegar eels, which are considered to be of great advantage as a live feed, will have beneficial effects on aquaculture.

As a result of the study, it is understood that vinegar eels need to be carried out in order to determine the optimum growth conditions and procedures for intensive culture and the use of bacterial proteins as live feeds is appropriate in terms of cost and adequacy.

\section{References}

Aas, T. S., Hatlen, B., Grisdale-Helland, B., Terjesen, B. F., Bakke-McKellep, A. M., \& Helland, S. J. (2006). Effects of diets containing a bacterial protein meal on growth and feed utilisation in rainbow trout (Oncorhynchus mykiss). Aquaculture, 261(1), 357-368.

Altinok, I., Balta, F., Capkin, E., \& Kayis, S. (2007). Disease of rainbow trout caused by Pseudomonas luteola. Aquaculture, 273(4), 393-397.

Austin, B., \& Austin, D. A. (1999). Bacterial Fish Pathogens: Diseases of Farmed and Wild Fish, 3rd ed. Springer-Praxis, London. $457 \mathrm{pp}$.

Bark, S., \& McGregor, D. (2001). The first occurrence of lactococcosis in farmed trout in England. Trout News, 31, 9-11.

Carson, J., Gudkovs, N., \& Austin, B. (1993). Characteristics of an Enterococcus-like bacterium from Australia and South Africa, pathogenic for rainbow trout (Oncorhynchus mykiss, Walbaum). $J$. Fish Dis., 16, 381-388.

Çağırgan H., (2007). Rainbow trout diseases. Eastern Anatolia Development Program, Agriculture and Rural Development Component, Van, 8-9pp.

Çağırgan, H. (2004). Biotyping of Lactococcus garvieae Isolated from Turkey. E.U. Journal of Fisheries \& Aquatic Sciences, 21, 267-269.

Çevik, M., \& Önalan, Ş., (2019). Bazı fitokimyasalların Yersinia ruckeri üzerine etkileri ve antimikrobiyal direnç durumlarının araştırılmast. (Yüksek Lisans Tezi). Van Yüzüncü Yıl Üniversitesi, Fen Bilimleri Enstitüsü, Van.

Diler, Ö., Altun, S., Adiloglu, Kubilay, A. K., \& A., Is1kl1, B. (2002). First occurrence of Streptococcosis affecting farmed rainbow trout (Oncorhynchus mykiss) in Turkey. Bull. Eur. Ass. Fish Pathol., 22, 21-26.

Duman, M., Saticioglu, I. B., Buyukekiz, A. G., Balta, F., \& Altun, S. (2017). Molecular characterization and antimicrobial resistance profile of atypical Citrobacter gillenii and Citrobacter sp. isolated from diseased rainbow trout (Oncorhynchus mykiss). Journal of Global Antimicrobial Resistance, 10, 136-142. 
Evans, J. J., Klesius, P. H., \& Shoemaker, C. A. (2009). First isolation and characterization of Lactococcus garvieae from Brazilian Nile tilapia, Oreochromis niloticus (L.), and pintado, Pseudoplathystoma corruscans (Spix \& Agassiz). Journal of Fish Diseases, 32(11), 943-951.

Eyngor, M., Zlotkin, A., Ghittino, C., Prearo, M., Douet, D. G., Chilmonczyk, S., \& Eldar A. (2004). Clonality and Diversity of the Fish Pathogen Lactococcus garvieae in Mediterranean Countries. Applied and Environmental Microbiology, 70 (9), 5132-5137.

Francis-West, P. H., Robertson, K. E., Ede, D. A., Rodriguez, C., Izpisua-Belmonte, J. C., Houston, B., Burt, D. W., Gribbin, C., Brickell, P. M., \& Tickle, C. (1995). Expression ofgenes encoding bone morphogenetic proteins and sonic hedgehog in talpid (ta3) limb buds: their relationships in the signalling cascade involved in limb patterning. Dev. Dyn., 203(2), 187197.

Gehenio, P. M., \& Luyet, B. J. (1951). Effect of a preliminary slight dehydration on the survival of 'vinegar eels' frozen at $-77^{\circ}$ C. Biodynamica, 7(130), 41-52.

Ghittino, C., \& Prearo, M. (1992). Report of Streptococcosis in rainbow trout (Oncorhynchus mykiss) in Italy: preliminary note. Boll. Soc. Patol. Ittica., 8, 4-9.

Gorgisen, G., Ozes, D., Pehlivanoglu, S., Erdogan, A., Dertsiz, L., Ozbilim, G., Ozbudak, I. H., Savas, B., \& Ozes, O. N. (2013). Differential expression and activation of Epidermal Growth Factor Receptor 1 (EGFR1), ERK, AKT, STAT3, and TWIST1 in nonsmall cell lung cancer (NSCLC). Experimental Lung Research, 39(9), 387-398.

Høiby, N., Bjarnsholt, T., Givskov, M., Molin, S., \& Ciofu, O. (2010). Antibiotic resistance of bacterial biofilms. International Journal of Antimicrobial Agents, 35(4), 322-332.

Lamason, R. L., Mohideen, M. A., Mest, J. R., Wong, A. C., Norton, H. L., \& Aros, M. C. (2005). SLC24A5, a putative cation exchanger, affects pigmentation in zebra fish and humans. Science, 310, 1782-1786.

Lee, S. Y., Vedamuthu, E. R., Washam, C. J., \& Reinbold, G. W. (1974). An agar medium for the differential enumeration of yogurt starter bacteria. Journal of Milk and Food Technology, 37(5), 272-276.

Olguín, E. J. (2012). Dual purpose microalgae-bacteria-based systems that treat wastewater and produce biodiesel and chemical products within a Biorefinery. Biotechnology Advances, 30(5), 1031-1046.

Øverland, M., Skrede, A., \& Matre, T. (2001). Bacterial protein grown on natural gas as feed for pigs. Acta Agriculturae Scandinavica, Section A-Animal Science, 51(2), 97-106.

Önal, U., Topaloğlu, G., \& Sepil, A. (2015). The Performance of Continuous Rotifer (Brachionus plicatilis) Culture System for Ornamental Fish Production. Journal of Life Sciences, 9, 207213.

Önalan, Ş., \& Yavuz, H. İ. (2019). Nanopartikül içerikli sıvı besiyerlerinde Lactococcus garvieae izolatlarının gelişim farklılıklarının spektrofotometrik olarak belirlenmesi. Menba Kastamonu Üniversitesi Su Ürünleri Fakültesi Dergisi, 5(1), 6-15.

Robin, J. H., \& Vincent, B. (2003). Microparticulate diets as first food for gilthead sea bream larva (Sparus aurata): study of fatty acid incorporation. Aquaculture, 225(1-4), 463-474.

Savvidis, G. K., Anatoliotis, C., Kanaki, Z., \& Vafeas, G. (2007). Epizootic outbreaks of Lactococcosis disease in rainbow trout, Oncorhynchus mykiss (Walbaum), culture in Greece. Bull. Eur. Ass. Fish Pathol., 27(6), 223-228.

Vendrell, D., Balca'zar, J. L., Ruiz-Zarzuela, I., Blas, D., Girones, O., \& Muzquiz, J. L. (2006). Lactococcus garvieaein fish: A review. Comparative Immunology, Microbiology\& Infectious Diseases, 29, 177-198.

Williams, C. M., Lee, C. G., Garlich, J. D., \& Shih, J. C. (1991). Evaluation of a bacterial feather fermentation product, feather-lysate, as a feed protein. Poultry Science, 70(1), 85-94. 